\title{
SOUTH AFRICA AT WAR, 1912-1982
}

Lt D. Conradie*

\section{Introduction}

The end of the Second Anglo-Boer War also put an end to the commando system that had been the core of military strength in South Africa. With the formation of the Union in 1910 it was realized that South Africa will have to provide its own defence. It was to be no easy task; seeing that the English and Afrikaans-speaking sections of the population had just concluded a bitter war which had left deep scars

\section{Birth of the Union Defence Force}

The Union Defence Act 13/12 made provision for a small permanent force, a citizen force recruited from volunteers, and a citizen reserve. This force could be called up for service anywhere in Africa. ${ }^{1}$ Thus began a new era in the military history of South Africa.

\section{World War I}

\section{The crisis of 1914}

The Defence Force was first used to suppress disturbances resulting from a miners' strike on the Witwatersrand in $19133^{2}$ The police were unable to control the strikes, but Defence Force units commanded by General De la Rey succeeded in breaking the strike.

The outbreak of World War 1 in August 1914 brought with it a severe crisis in South Africa. A large section of the Afrikaans-speaking population refused to serve against the Germans. It was considered a golden opportunity to regain the freedom lost in the 1899-1902 war. A considerable number of men went into armed rebellion against the government of General Botha. The bulk of the newly formed regiments were affected by this movement. ${ }^{3}$ Thirty thousand men were mobilised to suppress the rebellion, which caused much bitterness and delayed the invasion of German South West Africa.

\section{The campaigns in South West Africa and German East Africa}

With the rebellion something of the past, Botha established and trained a force of 50000 men, mostly mounted and with field artillery. A threepronged attack was launched upon the German Colony; from the south, Lüderitzbucht and from Walvis Bay. ${ }^{4}$ It was also during this campaign that the newly-formed South African Aviation Corps, equipped with all-steel Farman biplanes, first went into action. ${ }^{5}$ These aircraft provided invaluable information as to the movement of Colonel Franke's Schutztruppe. The Germans couldn't hold their own against this overwhelming force, and retreated northwards. On 9 July 1915 Franke surrendered. With the campaign in SWA over, the SAAC was dispersed. ${ }^{6}$

The next obvious sphere of participation was German East Africa, where a mixed British force was encountering strong and effective opposition from General Von Lettow Vorbeck's askaris. The German commander proved to be a man of exceptional capability. To make matters worse the topography, and the climate favoured the defenders.

In February 1916 Lieutenant-General J.C. Smuts took command of the British forces in the area. 17000 South African troops reinforced the hardpressed British. ${ }^{7}$ At the same time the newlyformed 26 Squadron of the Royal Flying Corps composed wholly of South Africans, arrived in East Africa.

The tasks allotted to the squadron were that of reconnaissance, bombing and communication. The task of reconnaissance was, however, severely hampered by the thick undergrowth. Smuts could not force the illusive Germans to surrender, and after a year he left for Europe. General Jacob van Deventer took over command, and succeeded in driving the German forces south across the border. The war in Europe had already ended when the gallant enemy eventually laid down his arms and peace returned to East-Africa. ${ }^{8}$ 


\section{Palestine and France}

By April 1915 the Union Government began to play with the idea of sending a well-equipped and experienced force to serve on the Western Front. In June 1915 it was agreed that 5 batteries of heavy artillery would be sent to Europe. In July 1915 recruiting for a full infantry brigade began in earnest. After completing its training in South Africa the 1st SA Infantry Brigade under the command of Brig-Genl H.T. Lukin, was shipped to England. In December the Brigade sailed for Egypt. Valuable experience was gained in the campaign where few casualties were suffered. By April 1916 the Brigade was in France, and joined up with the 9th Scottish Division.

\section{The carnage of the Somme}

On 24 June 1916 the long-awaited British summer offensive began with an immense artillery bombardment of the German lines in the Somme area. The bombardment continued for a week, and a total of 2 million shells were fired. ${ }^{9}$ On the 1st July 1916 the bombardment ceased, and the British and French infantry rose from their trenches and moved confidently over no-mans land towards the pulverized German lines. Their confidence was rudely shattered. The Germans rose from their deep re-inforced dug-outs and unleashed a withering machine-gun-fire on the masses of infantry. By the end of the first day the British alone had suffered 60000 casualties, and little ground was gained. Re-inforcements were brought up, and for the next few days the British battered themselves to pieces against a wall of German machine-guns and artillery. Losses on both sides were appalling. By 14 July 1916 the Somme-offensive entered a new phase: consolidation of the little ground that was gained, and an attempt to widen the small breach in the German front. The 1st SA Infantry Brigade was drawn into this endeavour. ${ }^{10}$

\section{Epic of Delville Wood}

On the morning of 14 July 1916 the 26th and 27th Scottish Brigades attacked Longueval and Delville Wood. However, the German defenders refused to give ground, and bitter hand-to-hand fighting ensued through Longueval. By the afternoon the town had still not been taken entirely. ${ }^{11}$ The Scots suffered heavy losses.

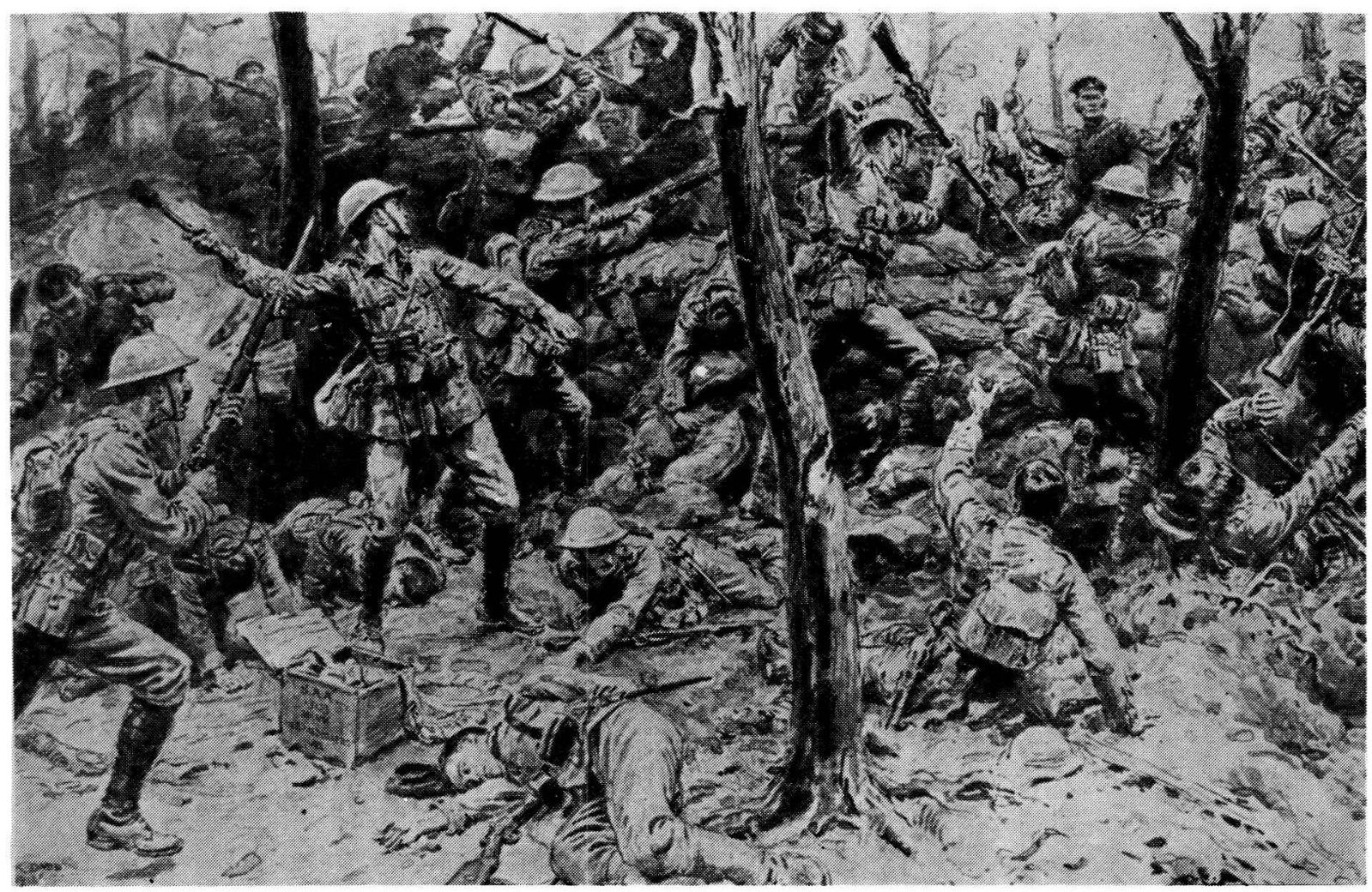

The Battle of Delville Wood, July 1916. Photograph taken from 'The Story of Delville Wood told in letters from the Front' 
At 05 h00 hours on the 15th the 1st SA Infantry Brigade was sent in to attack Delville Wood. ${ }^{12}$ Progress was slow, the thick tangle of trees with dense hazel thickets intersected by grassy rides impairing movement. Fallen trees and shell craters made matters more difficult for the heavilyladen troops. Despite these difficulties the South Africans succeeded in clearing and capturing all but the north-west corner of the wood. ${ }^{12}$

In expectation of counter-attacks the South Africans were instructed to dig in. This was almost impossible under the circumstances. The chalky soil was matted with roots and tangled with branches, so that construction of protective earthworks proved difficult. To make matters even worse the German trenches were only seventy yards away. The South Africans couldn't mount their machine-guns adequately either. ${ }^{13}$

The Germans were determined to retake what they had lost, and launched a series of counterattacks which were preceded by artillery bombaidment. On the 17th the battle for Delville Wood reached a pitch. The German artillery unleashed a bombardment on the wood that lasted for seven and a half hours. ${ }^{14}$ At 15 h 30 hours the bombardment ceased, and 9 battalions of German infantry assaulted the South African position. Fighting was desperate, and when ammunition was exhausted the struggle was continued with the bayonet.

By nightfall on the 18th the situation was so confused that the commanders on both sides had lost control of the battle. Small groups of Germans and South Africans continued the struggle amongst the tangled wreckage of the wood. The fighting continued, and even though the South Africans were in no condition to continue they were not relieved. Only after strong representations had been made to high command were the South Africans relieved. On the evening of 20 July 19163 officers and 140 men marched out of Delville Wood to rejoin the remainder of the Brigade. Of the original 132 officers and 3530 men who had gone into action at the start of the offensive, only 29 officers and 751 men had survived. ${ }^{15}$

\section{Flers and the price of victory}

In September 1916 the British High Command launched a third attempt at a breakthrough in the region of Flers. Between 9 and 19 October 1916 the 'rebuilt' 1st SA Infantry Brigade went into action once again near the Transloy at the Butte de Warlencourt. This time the casualty list exceeded $11000 .{ }^{16}$ By November the Somme-offensive had petered out, and the British Empire's casualty list stood at over 500000 .

Between April 1916 and November 1918 some 20000 volunteers served in South African combatant units on the Western Front. Of these almost 14000 became casualties. A high price for a country with limited manpower resources, but undeniable proof of the fighting spirit of the South African.

\section{Inter-war operations}

\section{The 1922-strike}

On the morning of 21 February 1922 the threat of violence became reality as the striking miners on the Reef vented their anger through the barrels of fire-arms. Bloody clashes between the strikers and the Defence Force was the result. As the Army had been reduced to its peace-time basis, units of the Active Citizen Force were called up to quell the disturbance. ${ }^{17}$

The newly-formed SAAF played a vital role in reconnoitring the positions of the strikers. The SAAF also carried out bombing raids on strikers in Benoni, Johannesburg, Springs, Boksburg and Brakpan. During these operations the SAAF suffered its first operational losses.

By 15 March 1922 the 'mini-war' was over. The SAAF had suffered 2 dead, 2 wounded and 2 aircraft damaged beyond repair. The new Air Force had, however, proved its worth for the strikers were totally demoralized by the strafing and bombing aircraft. ${ }^{18}$

\section{Operations in South West Africa}

In 1922 the Bondelswart Hottentots attacked settlers and plundered farms. Units of the UDF and the Police were immediately sent to the area to quell the uprising. The SAAF was to provide support for the ground forces. They engaged in bombing and strafing the rebels. On 2 June the rebels were defeated at Haibmund. ${ }^{19}$

In March 1925 the Rehoboths revolted. On the morning of 5 April 3 aircraft attacked the rebels, and within two hours the revolt was over. Due to the general unrest in the area the aircraft were, 
however, retained and the pilots undertook reconnaissance flights, and engaged in a display of power to discourage any further revolts. ${ }^{20}$

\section{World War II}

\section{East Africa - Baptism of fire}

The outbreak of war in September 1939 once again found the Union almost totally unprepared for war. General Smuts had to rebuild the Defence Force almost from scratch, but by the time Italy declared war in June 1940 the UDF was ready.

Italy had a powerful force in Abyssinia. The Duke of Aosta had under his command an army of 300000 men, 400 artillery pieces and 200 aircraft. ${ }^{21}$ While Italy procrastinated, the 1st SA Infantry Division, the SAAF, the Gold Coast Brigade and the Nigerian Brigade were rushed to East Africa.

At dawn on 11 June 1940 Junkers Ju-86 bombers of No 12 Squadron went into action, bombing and strafing Italian troop concentrations. ${ }^{22}$ From that moment on the SAAF didn't let go, and although they were outnumbered, and their Hawker Harts and Gloster Gladiators were not as agile as the Italian Fiat CR-32, and CR-42 fighters, the South African pilots gave a good account of themselves. In a relatively short time they gained air superiority, destroying over 100 enemy aircraft. ${ }^{23}$ The campaign also produced the first SAAF ace, Captain Jack Frost.

Early in 1941 the South African and other Allied forces began their two-pronged thrust into Italian territory. Within a short time the Juba line was broken, and the limited offensive became a campaign to drive the Italians into the mountains. It was in this offensive that the SA Tank Corps proved an outstanding success. In April 1941 the South Africans were the first to enter the Abyssinian capital, Addis Ababa. ${ }^{24}$

The last battles of the campaign were fought in steep, mountainous country. The enemy's positions were strong, well-sited and constructed in depth. The Italians fought with great determination at Amba Alagi, but in May 1941 the Duke of Aosta surrendered his forces. ${ }^{25}$

\section{The "little ships" of the Med - The Navy at War}

At the request of the British Admiralty, South Africa modified some whale-catchers and despatched these ships to the Mediterranean to assist the Royal Navy in anti-submarine patrols. Known as the 22nd Anti-submarine Group of the British Mediterranean Fleet, the 'little ships' went into action in January 1941, The first losses were suffered in February when the Southern Flow was completely destroyed by a floating mine; only one man surviving. ${ }^{26}$

In July and August 1941 the South African Naval presence in the theater was supplemented by five more ships. In December two more South African minesweepers joined the Fleet. ${ }^{27}$

One of the most hazardous operations in which the South African ships participated was convoy-duty to beleaguered Tobruk. Apart from the hazards presented by Axis submarines and surface ships, Nazi aircraft swarmed upon the convoys as they neared Tobruk. However, the 'little ships' and their crews gave stout service and served with honour throughout the war in the Mediterranean theatre.

\section{The Madagascar campaign ${ }^{28}$}

Early 1942 saw the Japanese Empire sweeping all the Allied forces away. A Japanese Naval task force entered the Indian Ocean. Madagascar became of critical strategic importance to Britain's supply lines. The continued Japanese successes made it necessary to occupy Madagascar as soon as possible, and a task force was assembled in Durban. A night landing was made on 4 May. The French defenders were caught by surprise and resistance was negligible. The SAAF provided valuable assistance with reconnaissance. Early in August 19427 SA Brigade was sent to the island to replace British troops needed in India. Further French resistance petered out on 5 November 1942

\section{North Africa - Disaster and triumph}

With the East African campaign at an end the South African Forces were sent to North Africa. This campaign was to teach the South Africans that victory wasn't always easy. Not only did the South Africans face a more resolute enemy, but living conditions in the desert proved to be difficult and extremely uncomfortable. 


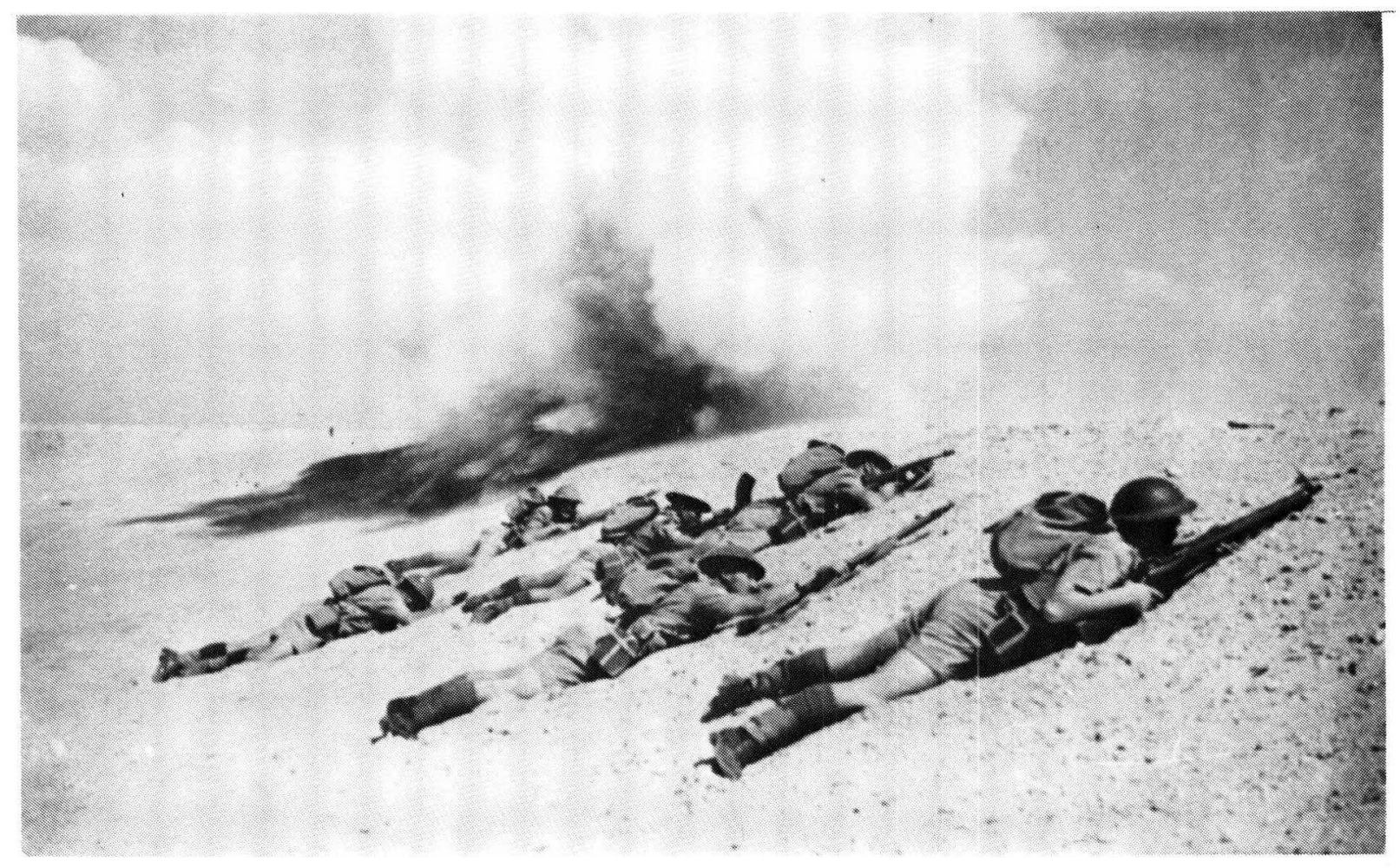

Training, North Arica, World War II

In November 19411 SA Division and 2 SA Division went onto the offensive with the British Eighth army. Expectations were high, and at first rewarded with success. Rommel was forced to withdraw. The South Africans took Bardia and Sollum. The sweetness of victory turned sour, however, when the 5th SA Brigade was annihilated by German tanks at Sidi Rezegh. Rommel retreated and then launched a counter-attack which forced the Eighth Army back to Gazala. ${ }^{29}$

In May 1942 Rommel's Afrika Korps launched an offensive that outflanked the Gazala Line. Crisis after crisis struck the Eighth Army. Outmanoeuvered by the 'Desert Fox' the British were forced to retreat to Egypt. Disaster struck South African arms when 2 SA Division was forced to surrender at Tobruk.

During the Eighth Army's hectic retreat, dubbed the 'Gazala Gallop', the South African Air Force played a significant role in bombing the advancing Afrika Korps, and in so doing gaining precious time for the British forces. The Bostons of 12 and 24 Squadrons started on a systematic bombing pattern, using eighteen aircraft that worked to a clockwork timetable. Known as the 'Boston Shuttle Service' because of its regularity and efficiency, they bombed day after day in immaculate formation. ${ }^{30} \mathrm{~A}$ terrible toll was taken of the enemy.
By 30 June Rommel reached the Alamein Line and launched several attacks on 1 SA Division which were successfully repulsed. By 4 July the enemy fell back to reorganise. ${ }^{31}$

While the two opposing armies were preparing for the next battle, furious air battles raged over the Alamein positions as the opposing air forces grappled for air superiority. The SAAF was in the thick of it. Heavy losses were suffered, but gradually the Luftwaffe and the Regia Aeronautica were beaten from the skies. ${ }^{32}$

On 23 October 1942 the Eighth Army went on the offensive. The days that followed produced fierce tank and artillery battles. The Axis defences wavered and then collapsed. Amidst all this 1 SA Division was participating in its last battle on African soil. On 3 November South African armoured cars slipped through the enemy lines and began raiding the enemy's rear areas, creating havoc in the process. The Axis forces were beaten and went into a headlong retreat, pursued by a relentless Eighth Army.

While 1 SA Division was withdrawn from operations the SAAF continued to participate in the pursuit, taking part in the final battles in Tunisia, which ended in the massacre of German transport aircraft at Cape Bon. ${ }^{33}$ 


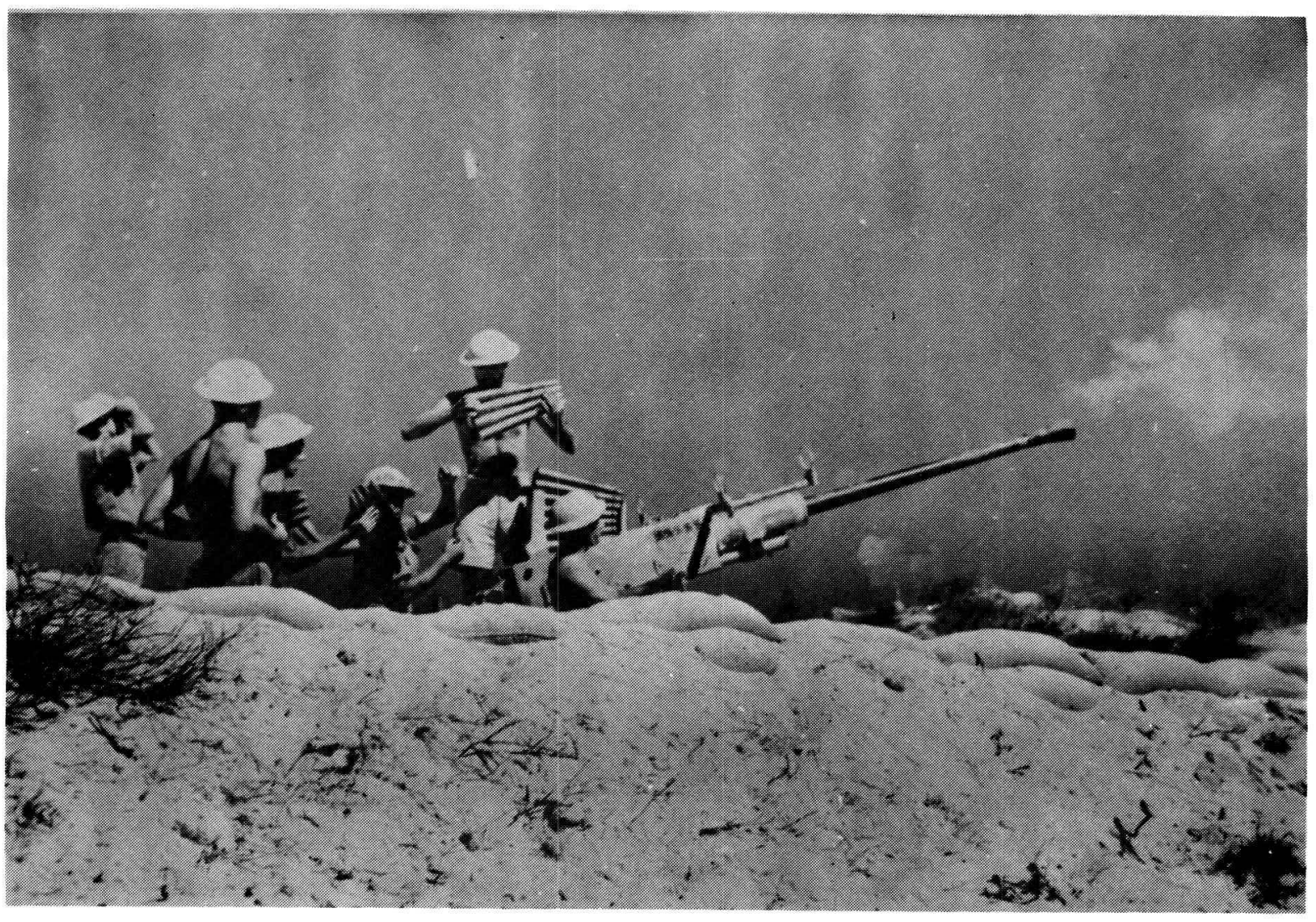

Bofors Gun in the Western Desert, World War II

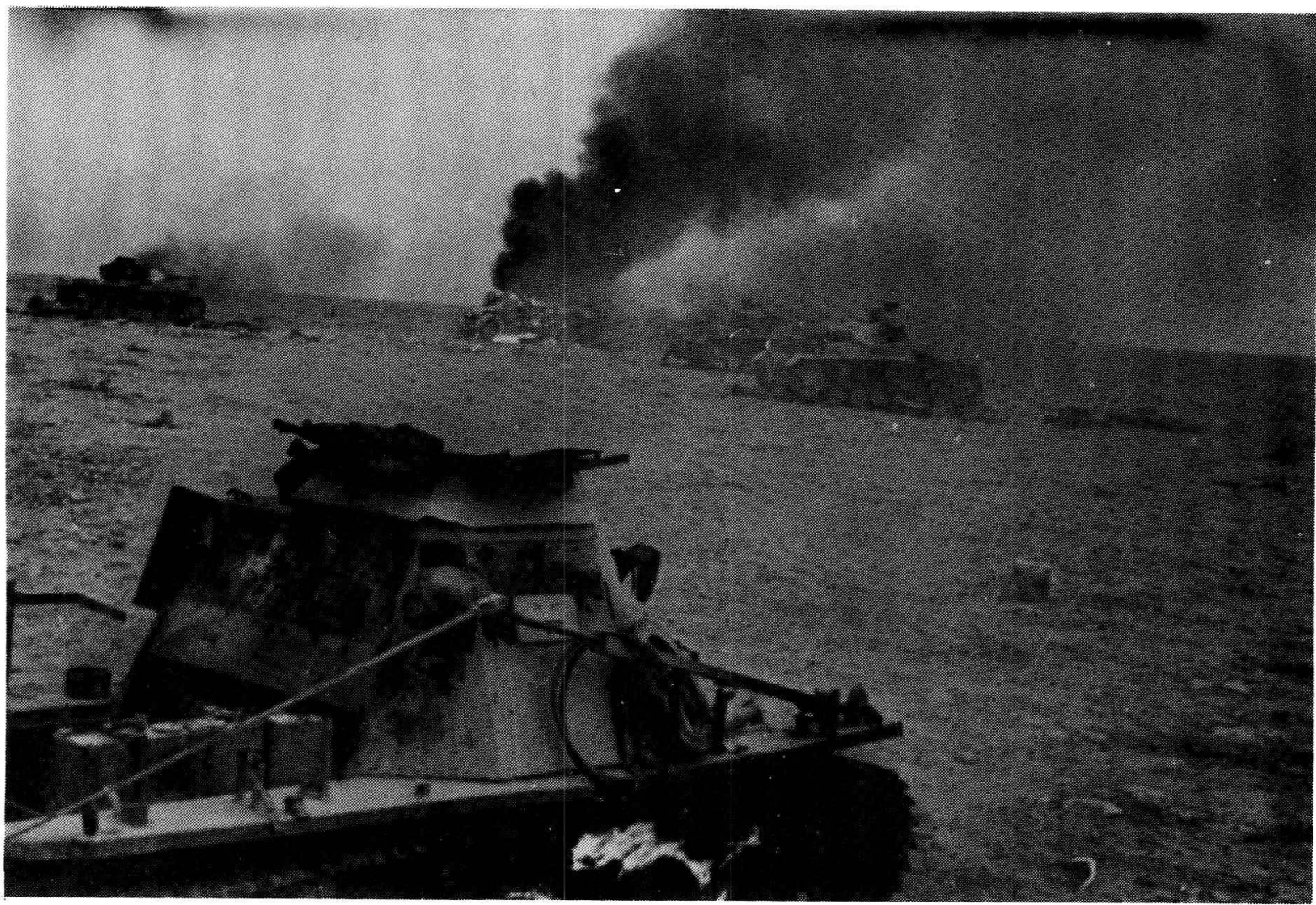

Tanks in the Western Desert, World War II 


\section{Victory in Italy}

In September 1943 American and Commonwealth Forces invaded Italy. The Allied landings at Salerno ran into fierce German resistance, and for a while failure seemed a strong possibility. The Allied air forces, the SAAF among them, provided superb support by clearing the skies over the beachhead of the Luftwaffe so that paratroops could be dropped. ${ }^{34}$ The SAAF continued its brilliant role throughout the whole campaign

In April 19446 SA Armoured Division arrived in Italy. Following the breakthrough at Cassino the Division joined the advance up the Liri Valley. After the fall of Rome the Division went into the spearhead of the advance. German opposition varied from slight to very determined. Near Florence German opposition became tenacious. The South African tanks recorded astonishing feats of manoeuvre on the steep hillsides. On 4 August 1944 the first Allied troops to enter Florence were South Africans. ${ }^{35}$

In September 1944 the Division came under command of the US 5th Army and participated in breaking the Gothic Line. 6 SA Armoured Division experienced some of the most savage fighting of the whole campaign when they clashed with the 16th SS Division. The Allied offensive petered out as the winter set in.

April 1945 saw the Springboks assaulting and capturing Monte Sole, Monte Caprara and Monte Abelle. The Germans fought tenaciously and only after bitter close-quarter fighting did the strongholds fall. ${ }^{36}$ German resistance cracked and the Allies began to pour into the Po Valley. Desperate and savage fighting characterized the last chapter of the campaign. The 6th SA Armoured Division succeeded in trapping a German division against the River Panaro at Finale. The battle ended in a terrible carnage. For three miles the roads leading to the bridge were a shambles of shattered weaponry with dead and dying men strewn about; a finale indeed. ${ }^{37}$

On 2 May 1945 all hostilities in Italy ceased.

\section{The Warsaw Concerto ${ }^{38}$}

In 1944 the Polish resistance rose against their oppressors, confident that the 'Russian steamroller' would assist them. The Russians did not act; consequently the Germans moved in and

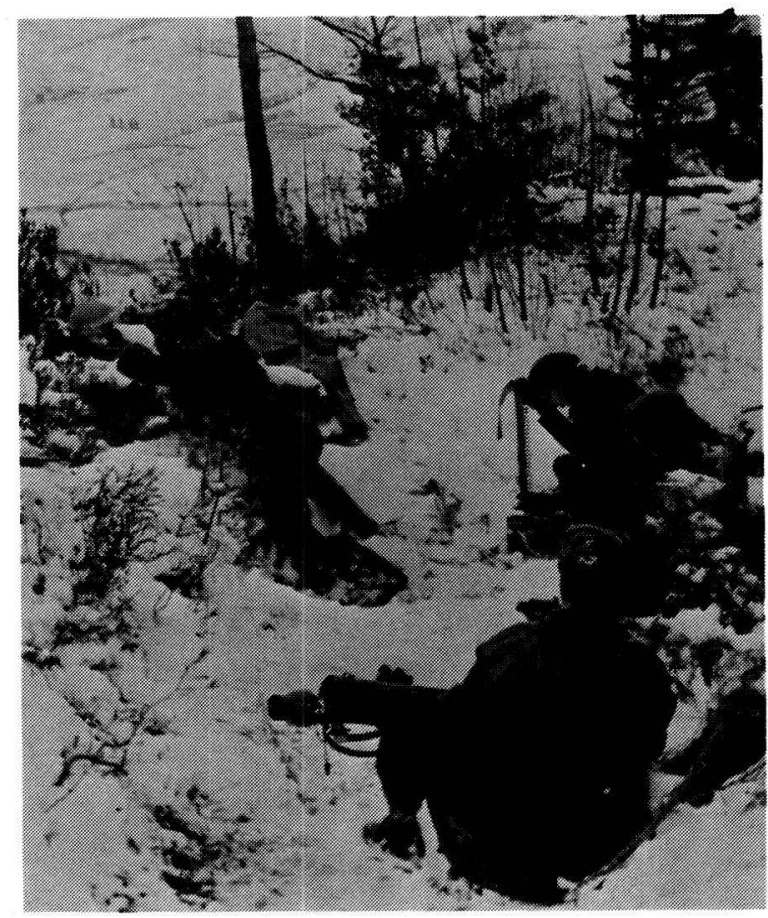

Italy, December 1944. South African troops prepare for action in the snow-covered Appenines

began a piecemeal destruction of Warsaw and the 'Home Army'. In August 1944 the Western Allies began their ill-fated attempt to supply the Poles by air. Once again the SAAF was a participant. The missions proved hazardous and losses were high. The partisans were, however, wiped out; the victims of international politics.

\section{The Berlin Airbridge $e^{39}$}

The debacle in Warsaw was, however, not the last operation in which members of the SAAF tried to keep a besieged city alive. In 1948 the Soviet Union closed all land routes to the city of Berlin. The West answered with the now famous 'Berlin Airbridge'. During this operation 20 SAAF aircrews flew 2500 missions and delivered 8333 tons of provisions to the city. Once again the SAAF had added to its proud record.

\section{Korea - The flying cheetahs}

In June 1950 Communist North Korea invaded South Korea, and by 16 November 2 Squadron SAAF was flying its first missions from Pusan. Equipped with outdated F-51 Mustangs the South Africans flew ground-strike missions against the enemy's supply lines. In July 1951 the Squadron encountered the first MiG fighters, but got away unscathed. The era of piston-engined fighters had come to an end. The Squad- 


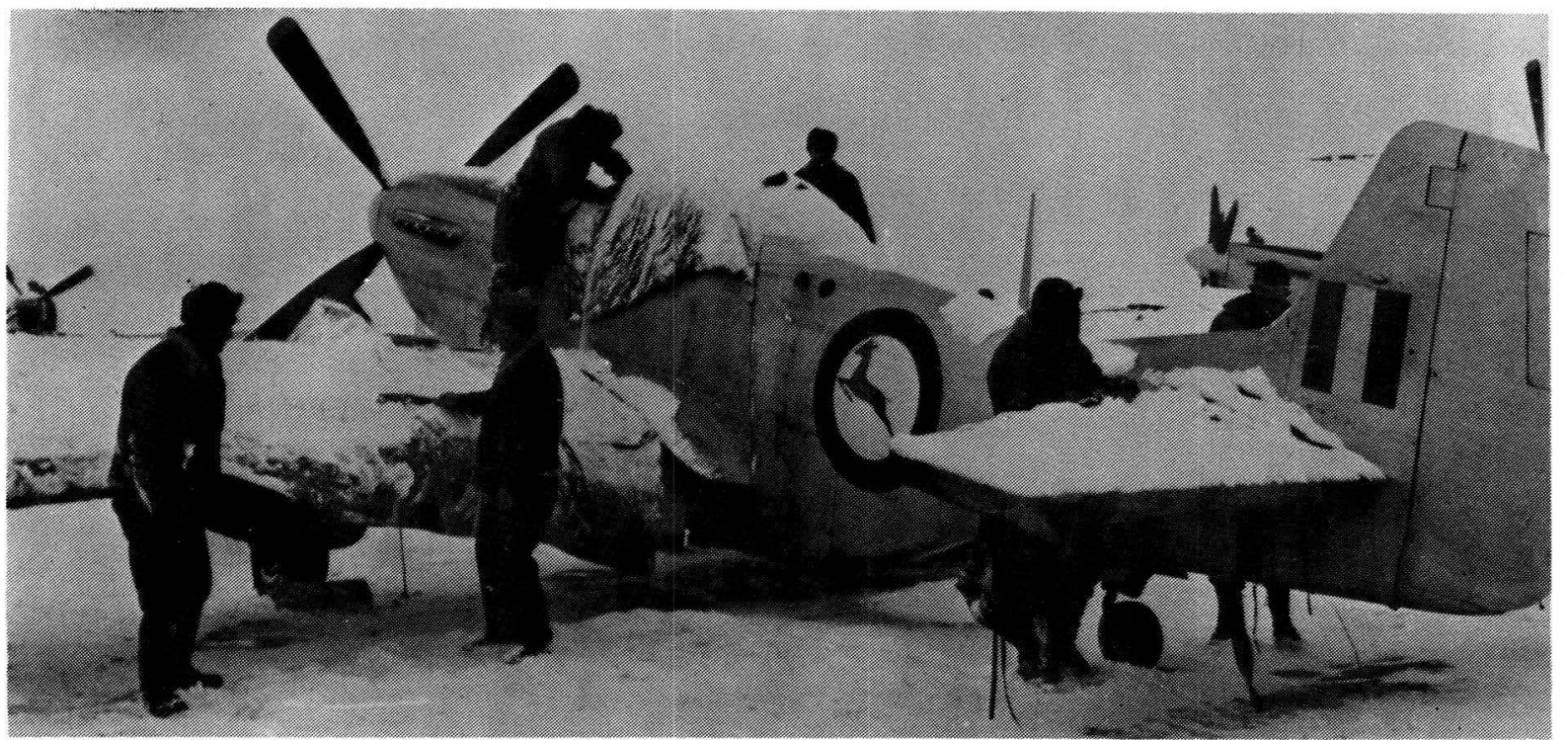

Maintenance on a Mustang of 2 Squadron SAAF in the freezing Korean winter

ron converted to F-86F Sabres, and by March the SAAF pilots flew their first missions in jet aircraft.

When 2 Squadron left Korea it had added to the impressive record of the SAAF 10597 sorties flown in Mustangs and 1470 missions flown in Sabres. 74 Mustangs out of a total of 95 were lost and 5 Sabres were shot down. The Squadron lost 34 pilots in action.

In recognition of their services the South Africans collected the following awards: Two Legions of Merit, two Silver Stars, 50 DFC's, one Soldiers Medal, 40 Bronze Stars, 176 Air Medals and 152 Clusters to the Air Medal. ${ }^{40}$
The Border War

Since the late 1960's the SADF has increasingly become involved in the insurgency war in South West Africa. This war proved to be far different from all previous wars the Defence Force had participated in. Nowhere in this war is there any movement of massive armies, large air-to-air battles, and bomber fleets bombarding enemy cities. The counter-insurgency war involves long, tiresome patrols on foot, on which the enemy is seldom seen. The terrorists do not seek direct battle with the security forces, but concentrates on the local population instead. The nature of this war is political, although SWAPO endeavours to change its tactics from time to time.

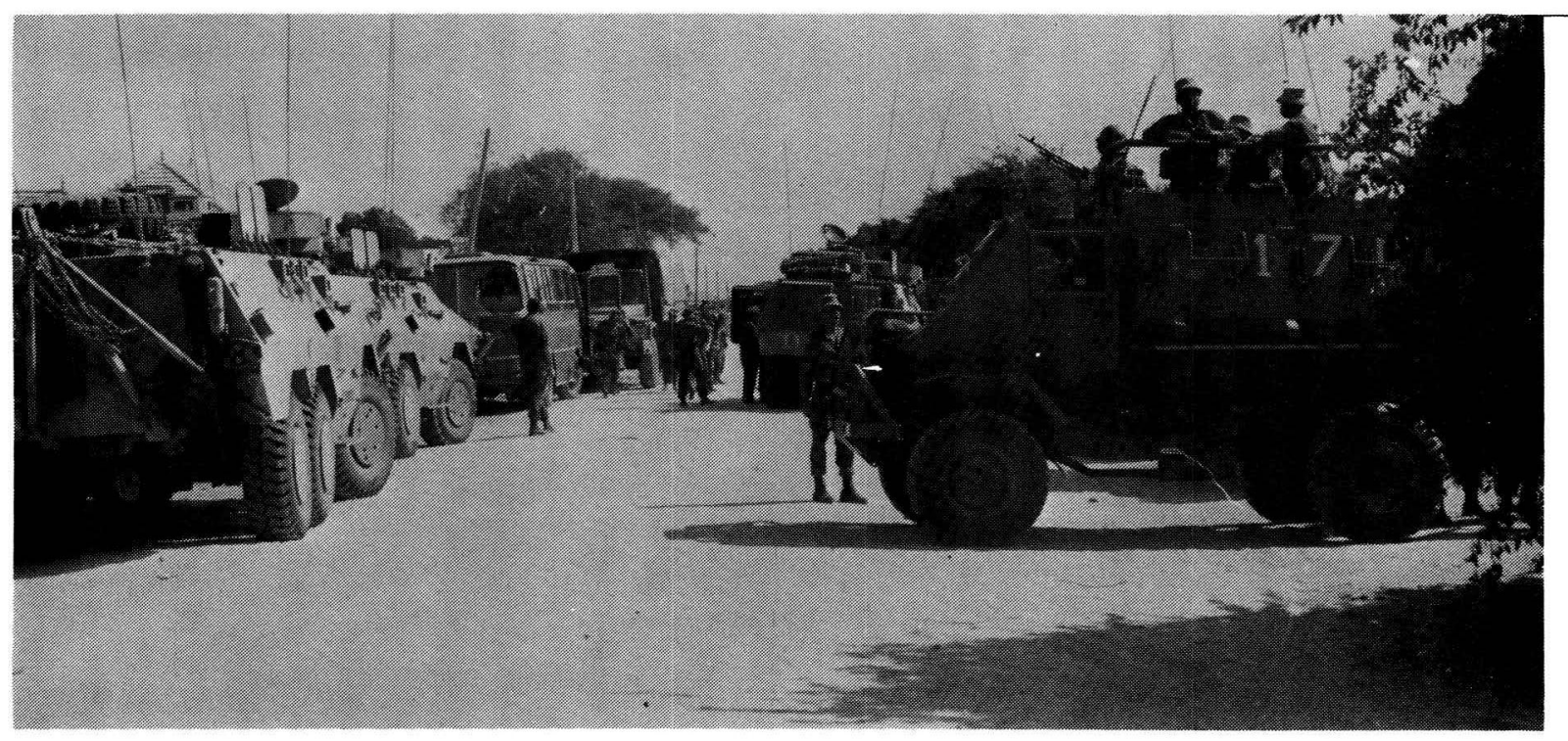

Strike into Angola! Photograph taken during the execution of Operation Protea 
It is with this object in mind that the SADF operates in SWA. Much time is spent on helping the local population when they need it, and care is taken not to interfere with tribal life.

During the Angolan Civil War South African troops were sent into Angola to protect South African interests. In ensuing clashes with Cuban forces, South African troops acquitted themselves well, indicating that they have lost none of the fighting spirit of their forefathers.

After South Africa terminated its involvement in the war, SWAPO moved into southern Angola, and tried to step up its campaign of terror in South West Africa. This necessitated the SADF to embark upon cross-border raids against the main centres of SWAPO. Notable operations of this type being Reindeer, Smokeshell, Protea and Daisy. A matter that became clear during these operations was the increasing co-operation between SWAPO and FAPLA, the Angolan Armed Forces. Naturally such close co-operation led to the South African Forces clashing with FAPLA as well; some of the clashes involving Russian-built tanks, artillery and aircraft. The South African Forces, however, have acquitted themselves well on each occasion, proving once more to be a well-trained, effective war machine even under extremely difficult conditions. The proud record continues.

* Lieutenant D. Conradie, B.A., is attached to the Military Information Bureau of the SADF.

\section{Footnotes}

1. Standard Encyclopedia of Southern Africa, Volume 7, Nasou, 1972, p 407.

2. Ibid, $p 407$

3. Ibid, $p 407$

4. Ibid, $p 408$

5. Per Aspera ad Astra - SAAF Golden Jubilee Souvenir Book 1920-1970, p 12.

6. Ibid p 15.

7. Ibid, $p 15$.

8. Standard Encyclopedia of SA, op cit, p 408.

9. Hockley, Maj Gen A.F., The Somme Barrage, Great Battles of the 20th Century, Hamlyn, London, 1977, p 51.

10. South Africa At War, Documentation Service, Pretoria, Sine Anno, p 3.

11. Ibid, p 3

12. Cornwell, R., Delville Wood: The South Africans in France April-July 1916, Militaria 7/2, Pretoria, 1977, p 42.

13. South Africa at War, op cit, $p 4$.

14. Ibid, p 5 .

15. Cornwell, R., op cit, p 54 .

16. Ibid, $p 54$.

17. Standard Encyclopedia of SA, op cit, $p 408$.

18. Per Aspera ad Astra, op cit, p 29.

19. Ibid, p 29 .

20. Ibid, $p 30$.

21. Klein, H., Springbok Record, Johannesburg, 1946, p 58.

22. Per Aspera and Astra, oo cit, p 36.

23. Klein, H., op cit, $p 65$.

24. Standard Encyclopedia of SA, op cit, p 409.

25. Klein, H., op cit, p 162.

26. Goosen, Comm J.C., South Africa's Navy: The First Fitty Years, Flesch and Partners, Cape Town, 1973, p 53.

27. Ibid, $p 54$.

28. Brown, J.A., Eagles Strike, Purnell, Cape Town, 1974, p 383.

29. Klein, H., op cit, p 208.

30. Per Aspera ad Astra, op cit, p 54.

31. Klein, H., op cit, p 214.

32. Brown, J.A., op cit, pp 203-283.

33. Ibid, pp 374-382.

34. Per Aspera ad Astra, op cit, pp 79-84.

35. Klein, H., op cit, p 247.

36. Ibid, $p 247$.

37. Ibid, $p 244$

38. Per Aspera ad Astra, op cit., pp 88-89.

39. Ibid, $p 110$.

40. Ibid, p 119. 